\title{
44. HYDROTHERMAL ALTERATION OF BASALTS AND SEDIMENTS AT DEEP SEA DRILLING PROJECT SITE 456, MARIANA TROUGH ${ }^{1}$
}

\author{
James H. Natland, Deep Sea Drilling Project, Scripps Institution of Oceanography, La Jolla, California \\ and \\ Roger Hekinian, Cenitre Océanologique de Bretagne, 29273 Brest, France
}

\begin{abstract}
Basalts in two holes spaced 200 meters apart at DSDP Site 456 in the Mariana Trough both show a downward sequence of nonoxidative and oxidative zones of alteration, each 10 to 15 meters thick, overlying fresh basalts. Basalts in the nonoxidative zone have been extensively chloritized and have vein and vesicle fillings of quartz, opal, chlorite, calcite, and pyrite. Minor sulfides are chalcopyrite and digenite. Basalts in the oxidative zone have abundant smectites and iron hydroxides and are variably enriched in $\mathrm{K}, \mathrm{Rb}$, and $\mathrm{Ba}$, unlike the nonoxidative basalts above them. We propose that the oxidative zone was a zone of mixing between high-temperature, reduced hydrothermal fluids moving horizontally beneath impermeable sediments at the top of the pillowed basement lavas and cold, oxygenated seawater in interpillow voids deeper in the basement. Recrystallized vitric tuffs immediately above the basalts containing authigenic quartz and wairakite, as well as occurrence of chlorite, epidote, and chalcopyrite in the basalts, suggest temperatures of alteration in excess of $200^{\circ} \mathrm{C}$.
\end{abstract}

\section{INTRODUCTION}

During Leg 60, hydrothermally altered rocks were recovered at two sites in the Mariana Trough. One of these was Site 453 at the western edge of the trough, where chloritized and demagnetized gabbros and metabasalts occur in two zones in a complex polymict breccia sequence. The second occurrence was at Site 456 (Fig. $1)$, where the altered rocks are pillow basalts. The effects of alteration at both sites are discussed in the relevant site chapters in this volume. Additional information on Site 453 is in Natland (this volume) and in Lawrence and Natland (this volume). Here we present descriptions and electron microprobe minerals analyses of alteration products and unaltered feldspars at Site 456 and offer a hypothesis on the origin of the alteration.

\section{SETTING}

Site $456\left(17^{\circ} 54.7^{\prime} \mathrm{N} ; 145^{\circ} 10.8^{\prime} \mathrm{E}\right)$ is in 3591 meters of water on the edge of an apron of volcaniclastic sediments derived from the active Mariana arc. This apron drapes from the arc, thinning to the west, into the Mariana Trough. The site was selected as an alternate target after drilling at the original Mariana apron site (455) proved impossible because of instability of coarse volcaniclastic sediments in the hole. Site 456 was drilled behind a somewhat protective basement high, around which the coarser sediments derived from the arc were deflected. Although this allowed the drill string to reach basement, there were only 114 meters of sediment in Hole 456 and 95 meters in a second hole about 200 meters to the east, Hole 456A.

The second hole was drilled primarily to evaluate the lateral extent of hydrothermal alteration, which was im-

\footnotetext{
${ }^{1}$ Initial Reports of the Deep Sea Drilling Project, Volume 60.
}

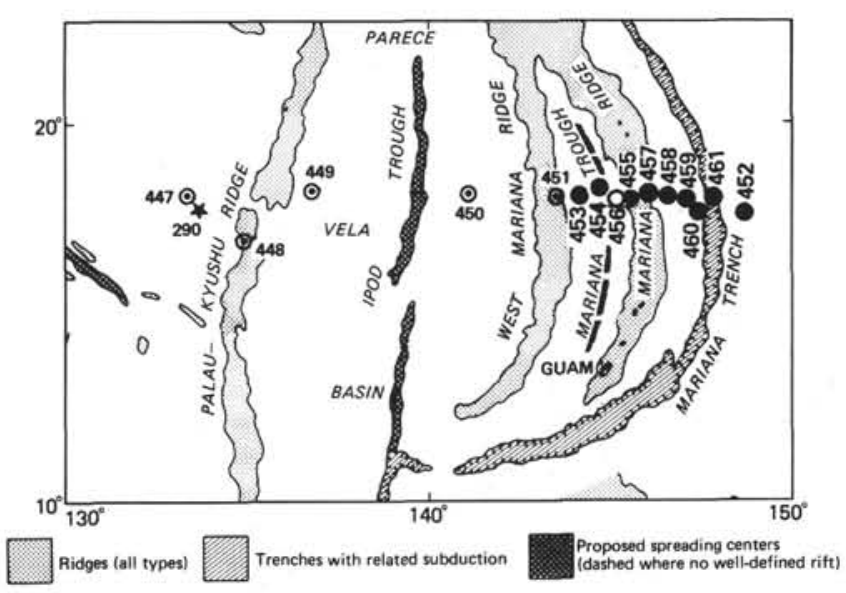

- Other Sites drilled during Leg $60 \quad$ ○ Leg 59 Sites $\star$ Site 290, Leg 31

Figure 1. Location of Site 456 (open circle) in the Mariana Trough.

mediately evident with the recovery of basalts from the first Hole, 456. In neither hole was basement penetration exceptional $(35.5 \mathrm{~m}$ in Hole $456,45.0 \mathrm{~m}$ in Hole $456 \mathrm{~A}$ ) and ended because of drilling difficulties in both cases. In fact, it was necessary to shoot off the bottomhole assembly in Hole 456A because the drill string became stuck in the hole.

\section{HYDROTHERMAL ALTERATION}

The remarkable feature of the hydrothermal alteration at Site 456 is that it is concentrated at the top of the basalts in both holes (Fig. 2). With increasing depth, three zones of diminishing alteration occur in the two holes:

1) a zone of nonoxidative alteration in which the basalts, all pillows (Fig. 3), are extensively chloritized and 

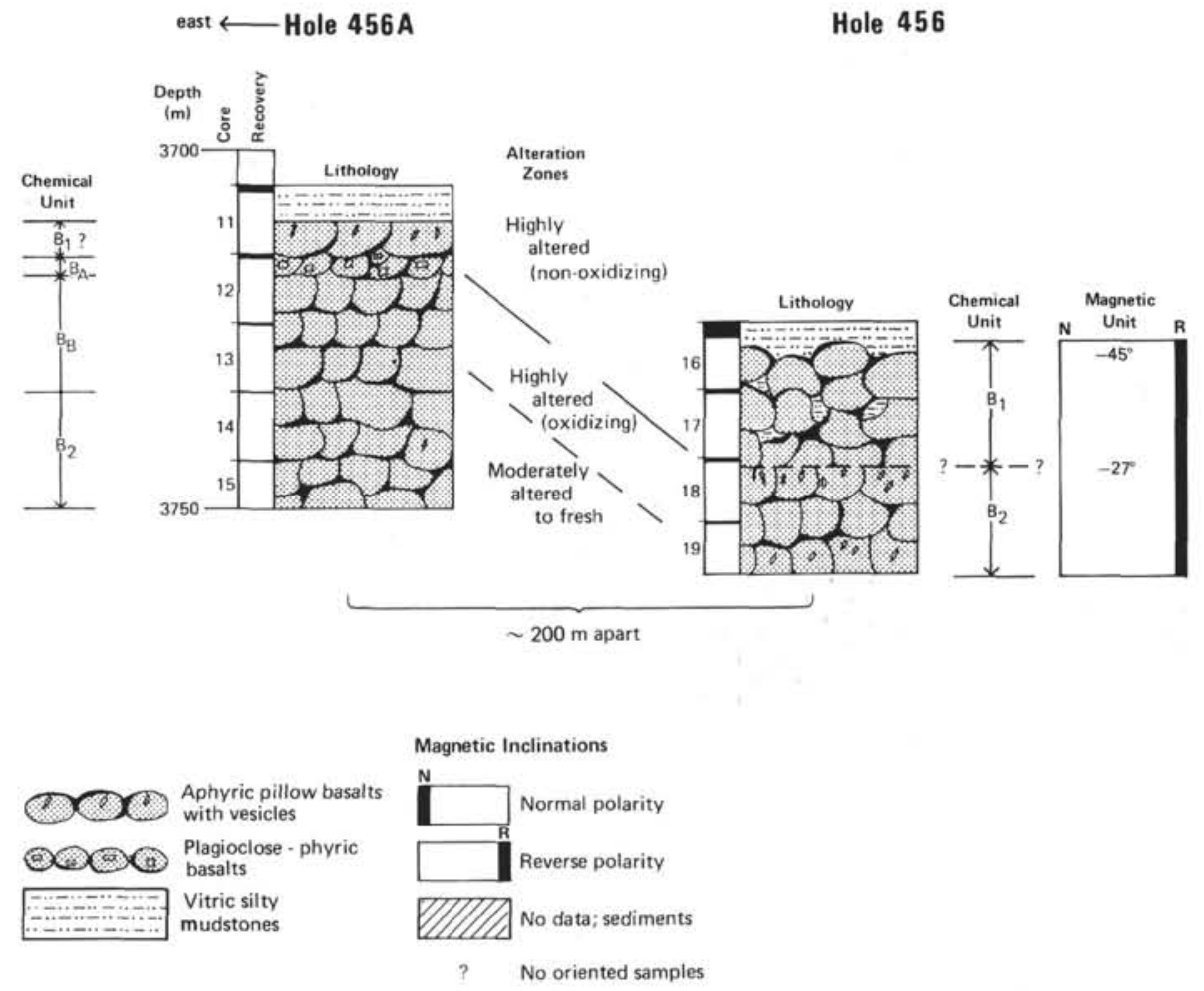

Figure 2. Igneous lithology, lithologic units, chemical units, and magnetic inclinations for the two holes drilled at Site 456. Inclined solid and dashed lines between the two holes indicate zones of nonoxidative and oxidative alteration, respectively.

in which vesicles are filled with quartz, opal, chlorite, calcite, pyrite, and other sulfides (Figs. 4 and 5);

2) a zone of oxidative alteration in which the pillows are altered to brown or reddish brown and the main secondary minerals are smectites and iron hydroxides;

3) unaltered basalt, including fresh glass in both holes.

In Hole 456, Zone 1 is about 18 meters thick, and in Hole 456A it is less than 10 meters thick. In both holes, recovery was higher in this zone because of easy drilling.

The transition from Zone 1 to Zone 2 is gradational, occurring over about 5 meters (estimated) in which there are alternating pieces with predominantly green, or chloritic, alteration and pieces with brownish or ironhydroxide alteration. The entire zone of oxidative alteration extends for about 10 meters below this, although this is difficult to estimate with certainty because of low recovery. Zone 3, fresh basalts, is not entirely without alteration, but it is of low intensity. There are some pieces with probable low-temperature alteration rinds. Recovery was very low in the deepest (least altered) cores of both holes.

\section{MINERALOGY}

To determine the secondary mineralogy, we used petrographic, X-ray diffraction, scanning electron microscope, and electron microprobe techniques. X-ray diffraction established that chlorite predominates in the nonoxidative Zone 1 and trioctahedral smectite in the oxidative Zone 2. Several samples from Zone 1 were in- vestigated by microprobe. The samples were variably plagioclase phyric or microphyric, with groundmass plagioclase microlites and spherulites. Glass, clinopyroxene, and opaque minerals were completely transformed to secondary minerals.

Plagioclase analyses are listed in Table 1 . The compositions are variable, and there is a definite trend of decreasing An content from phenocryst to groundmass phases. All of this appears to reflect primary magmatic processes, however, as there are no sodic plagioclases (oligoclase or albite) such as occur in some seafloor greenstones (Cann, 1969; Humphris and Thompson, 1978).

Secondary silicates analyzed are chlorite and sphene (Table 2). The latter mineral evidently has taken up much of the $\mathrm{TiO}_{2}$ originally in titanomagnetites. Epidote was also identified with the microprobe but was not analyzed. The chlorite is ripidolitic in composition, with $\mathrm{MgO} / \mathrm{FeO}$ * of about one, and resembles chlorites in greenstones described from the Mid-Atlantic Ridge (Melson and van Andel, 1966; Humphris and Thompson, 1978).

Secondary sulfides were analyzed in two samples (Table 3). Pyrite was identified in both, with a fairly $\mathrm{Cu}$ rich pyrite in one of them that may actually represent a tiny, optically unresolvable chalcopyrite grain intersected by the microprobe beam, since chalcopyrite and digenite were also found in that sample. The digenite occurred as an inclusion within a pyrite grain. Petrographically, the sulfides occur as vesicle fillings associ- 


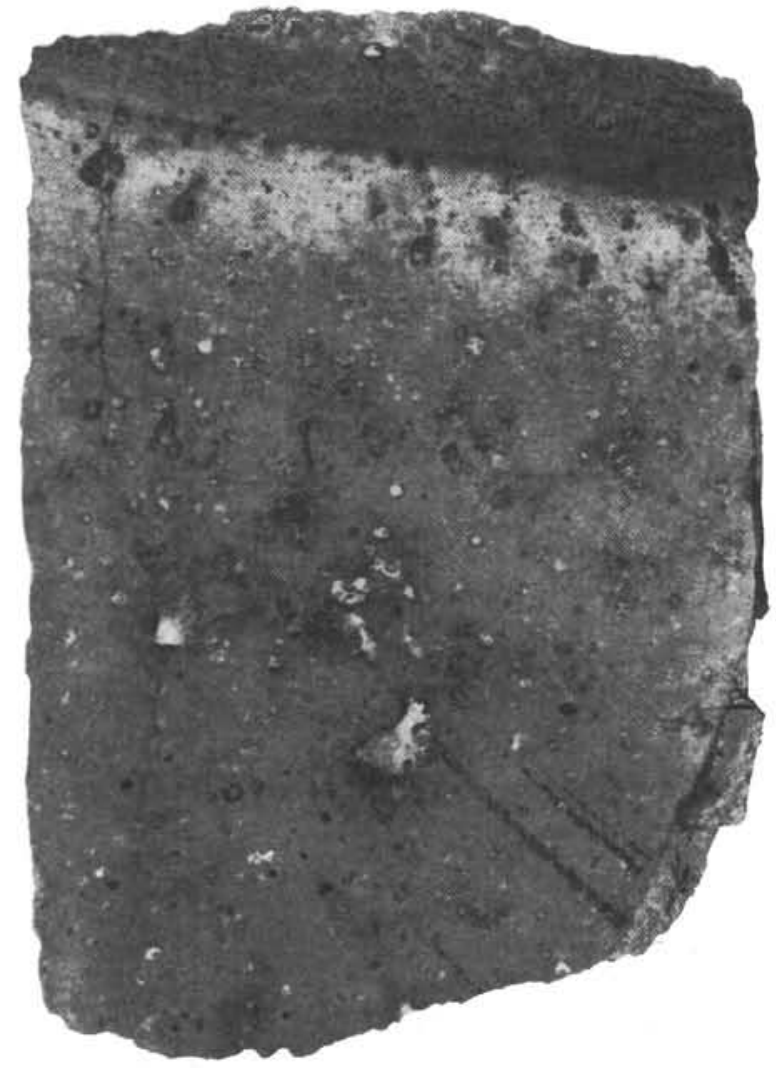

A

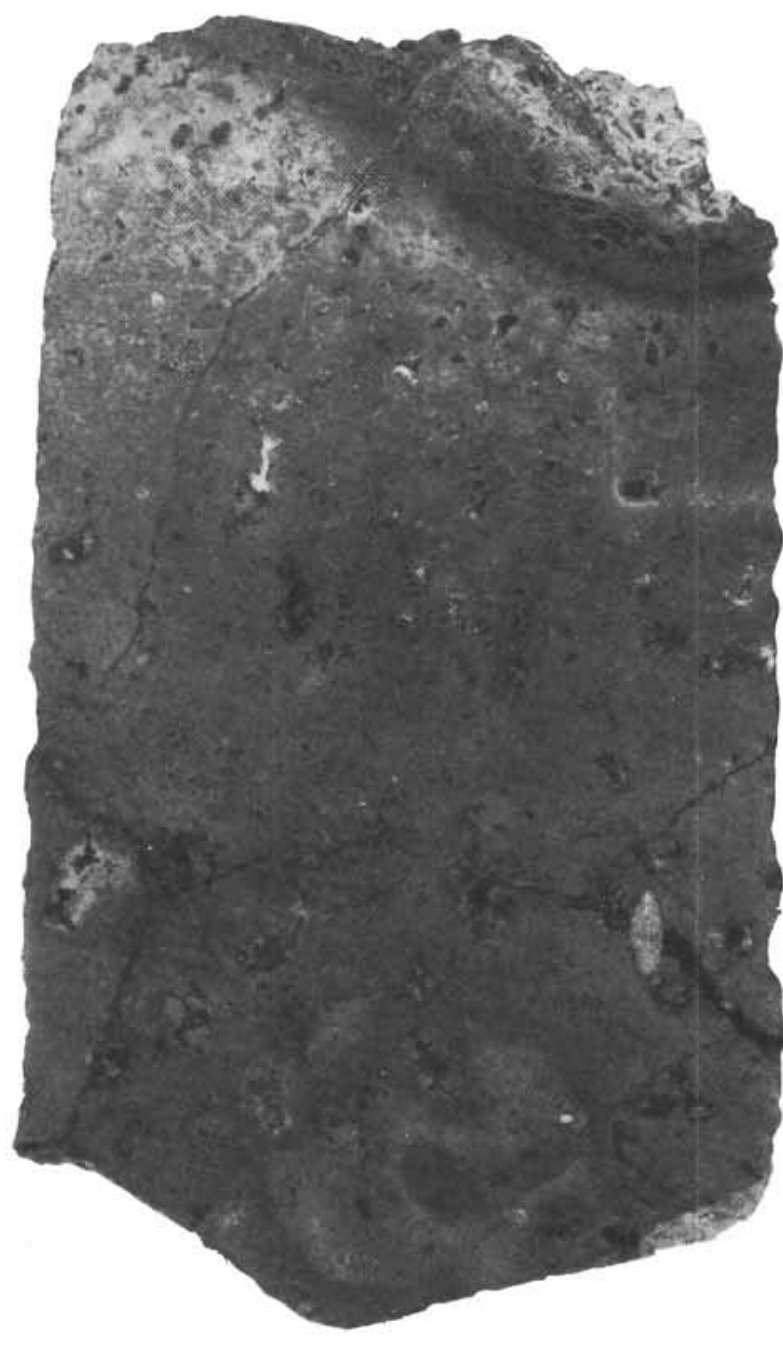

B

Figure 3. Altered rims of pillow basalts showing remnants of glassy rinds (top of each piece) in the zone of nonoxidative alteration. A. Sample 456-16-1 (Piece 10a, 84-93 cm). B. Sample 456-16-2 (Piece 1a, 2-12 cm).

ated with quartz and seem to have filled in permeable grain-boundary zones in the solid rock (Fig. 4).

\section{EFFECT OF ALTERATION ON ROCK CHEMISTRY}

Contrasting chemical effects are evident in the wholerock compositions of Zones 1 and 2, using data listed in Wood et al. (this volume). The effects are somewhat difficult to evaluate because there are several distinct chemical types of basalt found in the two holes, and the different types of alteration occur on basalts of different composition. Nevertheless, basic trends can be discerned. Based on the chlorite analyses given in Table 2 , wholesale alteration of a basalt to a mineral assemblage dominated by chlorite should increase $\mathrm{MgO}$ and decrease $\mathrm{CaO}$ considerably. A smaller increase in iron should also occur. Basalts in which calcite has been precipitated, however, might actually have an increase in $\mathrm{CaO}$ rather than a decrease. Pyrite in a basalt will also increase the iron. These various effects seem evident in the first three analyses in Table 4. All three are from what was originally a chemically homogeneous basalt type ( $B_{1}$ on Fig. 2), as defined by very similar contents of presumed stable oxides and trace elements such as $\mathrm{TiO}_{2}$ and $\mathrm{Zr}$. The most magnesian of the three is also the least calcic, and the most calcic is probably rich in calcite. None of the basalts has been enriched in $\mathrm{K}_{2} \mathrm{O}$ or $\mathrm{Rb}$, consistent with the low abundances of these elements in chlorite. Both $\mathrm{Zn}$ and $\mathrm{Pb}$ are highest in the sample with-highest iron, evidently because the sample has abundant sulfides.

Variations similar to these have been noted in other seafloor basalts altered to greenschist facies (Humphris and Thompson, 1978). The effect of MgO enrichment and $\mathrm{CaO}$ depletion has also been produced experimentally by reacting basalt glass with seawater at elevated 


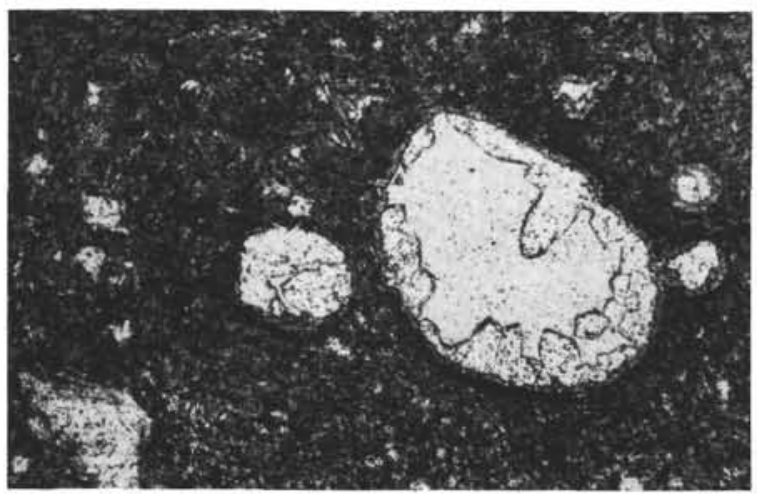

A

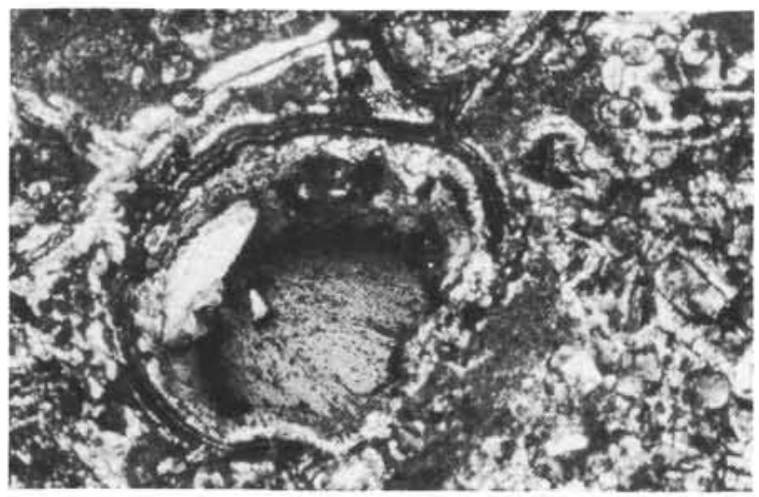

B

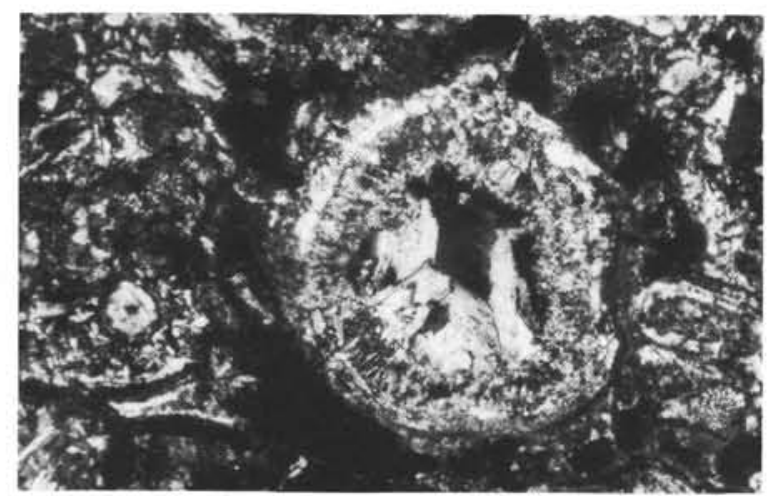

C

Figure 4. Photomicrographs of vesicle fillings in basalts. A. Sample 456-A-11-1, 76-78 cm. Silica mineral (quartz? opal?) in vesicle, plane polarized light. B. Sample 456-16-1, 146-148 cm. Opal in vesicle, crossed nichols. C. Sample 456-16-1, 146-148 cm. Claylined vesicle filled with opal(?) and quartz.

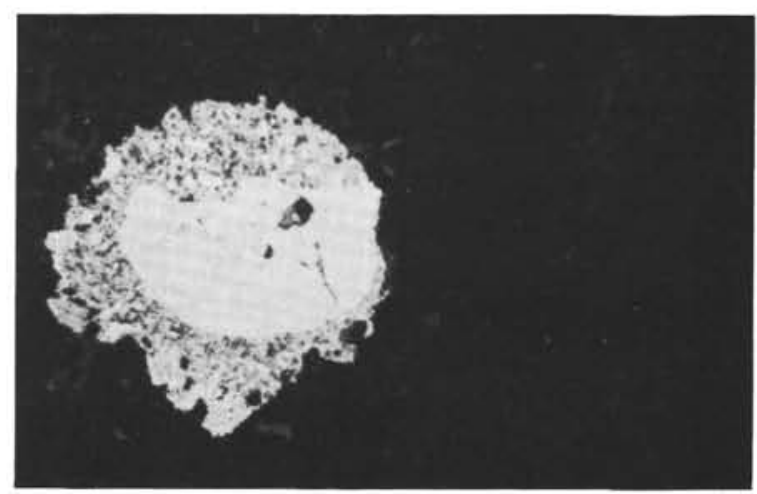

A

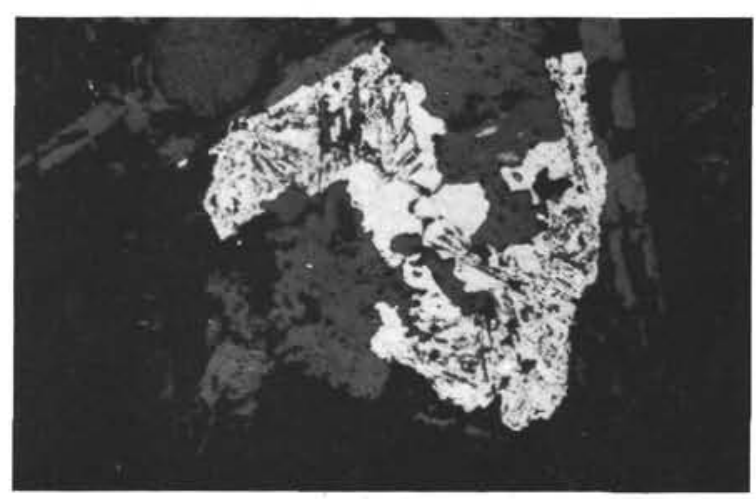

B

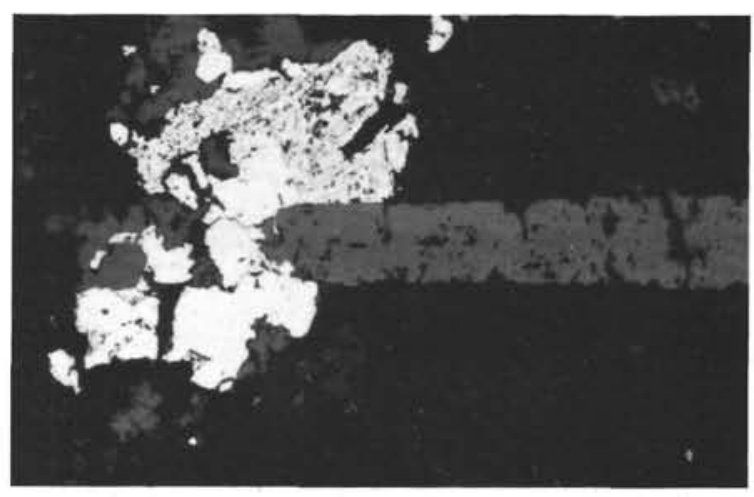

C

Figure 5. Photomicrographs of pyrite in Sample 456-16-1, 146-148 $\mathrm{cm}$. A. In vesicle and around crystals near vesicle. B. Intergrown with skeletal plagioclase clump. C. Intergrown with plagioclase microphenocrystal aggregate. 
temperatures to form, among other minerals, chlorite (e.g., Seyfried and Bischoff, 1977; Mottl and Holland, 1978).

In Zone 2, where alteration was oxidative, $\mathrm{K}_{2} \mathrm{O}$ reaches values between 0.40 and $0.98 \%$ (see Analysis 4, Table 4). $\mathrm{Rb}$ enrichment parallels $\mathrm{K}_{2} \mathrm{O}$, ranging from 4 to 12 parts per million in the same basalts. $\mathrm{Ba}$ is higher by a factor of about two in the $\mathrm{K}$ - and Rb-rich rocks. Since sulfides are absent, $\mathrm{Zn}$ is only 34 to 86 parts per million compared with the higher abundances for chloritized basalts listed in Table 4 .

\section{ALTERATION IN THE SEDIMENTS}

Recrystallized vitric tuffs occur just above the basalts in Hole 456 (Fig. 6, A and B) and as an inclusion in one of the basalts (Fig. 6C). These are indurated samples that have clearly been subjected to the same, or nearly the same, degree of alteration as the basalts. Like the basalts that enclose it, for example, the inclusion has been pyritized.

$\mathrm{X}$-ray diffraction analysis revealed that the indurated sediment sample just above the basalt in Hole 456 (Fig. $6 \mathrm{~b})$ contains quartz and an analcime-like mineral. Scanning electron microscopy shows that the quartz is clearly authigenic in origin (Fig. 6D). An energy-dispersive analyzer attached to the SEM established that the other mineral, which forms quite large and perfect crystals, is not analcime but its calcic isomorph, wairakite. Additional X-ray diffraction analysis of sediments higher in the hole (Balshaw, this volume; Latouche et al., this volume) indicates that the wairakite may occur throughout the sediment column at the site.

\section{TEMPERATURE ESTIMATE OF THE ALTERATION}

The wairakite is important, for it indicates that temperatures of alteration may have been quite high - in excess of $200^{\circ} \mathrm{C}$. Liou (1971) investigated the stability of wairakite in the system $\mathrm{CaAl}_{2} \mathrm{Si}_{2} \mathrm{O}_{8}-\mathrm{SiO}_{2}-\mathrm{H}_{2} \mathrm{O}$. Specifically, it forms as a dehydration product of laumontite at low pressures only above $200^{\circ} \mathrm{C}$. Mottl and Holland (1978) identified either analcime or disordered wairakite by its X-ray pattern among the products of a sealed reaction at $300^{\circ} \mathrm{C}$ between basalt glass and seawater. Seki (1973) summarized the occurrence of wairakite in active and fossil geothermal areas in the Japanese island arc. It is found, for example, in the deeper parts of a number of active geothermal areas associated with quartz and chlorite, or a mixed-layer clay, and with pyrite. Maximum temperatures of the wairakite occurrences in bore holes in these areas are near $200^{\circ} \mathrm{C}$. Tomasson and Kristmannsdottir (1972) and Kristmannsdottir (1976) found the transition between zeolite and greenschist facies in the Reykjanes (Iceland) geothermal system to occur between $200^{\circ} \mathrm{C}$ and $300^{\circ} \mathrm{C}$. Chlorite first appears between $230^{\circ}$ and $280^{\circ}$. Epidote is a minor phase at $200^{\circ}$ and a major phase about $260^{\circ}$ to $270^{\circ}$. Analcime and minor wairakite occur about $230^{\circ}$. Quartz, K-feldspar, calcite, anhydrite, and pyrite occur in varying amounts throughout the system. A similar paragenesis occurs in sandstones, siltstones, and shales in the Cerro Prieto geothermal system at the head of the Gulf of California. There wairakite occurs only between temperatures of $200^{\circ}$ to $340^{\circ}$ and is most abundant between $250^{\circ}$ and $300^{\circ}$, chlorite occurs from about $150^{\circ}$ to $350^{\circ}$ but becomes abundant only over $200^{\circ}$, and epidote is abundant only above $250^{\circ}$ (Elders et al., 1979). Wairakite is listed among a group of calcium aluminum silicates formed as a result of "decarbonation reactions." This may also have occurred in the lowermost sediments at Site 456.

All in all, these comparisons suggest that alteration at Site 456 occurred at least at $200^{\circ} \mathrm{C}$ and probably closer to $250^{\circ} \mathrm{C}$. We add to this the conclusion from experimental data by Crerar and Barnes (1976) that copperbearing ore minerals form from complexes in solutions usually above $250^{\circ} \mathrm{C}$, although perhaps our data are more a confirmation of their conclusions than vice versa, given the small amounts of chalcopyrite and digenite in our samples.

\section{A ONE-STAGE ALTERATION MODEL FOR SITE 456}

The temperatures just suggested for alteration at Site 456 are not surprising in view of the high temperatures (ca. $350^{\circ} \mathrm{C}$ ) of hot water vents emitting sulfides directly onto the seafloor at the crest of the East Pacific Rise near $21^{\circ} \mathrm{N}$ (e.g., Edmond, Craig, et al., 1979; RISE Scientific Team, 1980). Site 456 itself is only a few kilometers away from an active spreading center in the Mariana Trough, and the alteration described here may well have occurred at the trough axis. The occurrence of pyrite and copper-bearing sulfides at Site 456 and the detectable enrichments of $\mathrm{Zn}$ in some of the samples are other points of similarity, although to be sure, extensive sulfides with a major zinc sulfide (sphalerite) component were not recovered at the site, even though they are abundant at $21^{\circ} \mathrm{N}$ (Hekinian et al., 1980; Haymon and Kastner, in press).

The comparison to the East Pacific Rise $21^{\circ} \mathrm{N}$ occurrences that we would like to emphasize is that the pathways for high-temperature fluids in both cases seem to have been very narrow. The sulfide vents at $21^{\circ} \mathrm{N}$ occur in a restricted zone along the zone of axial intrusion at the rise crest. The vents themselves are small pillars through which high-temperature, sulfide-charged waters emerge at considerable hydraulic force (e.g., RISE Scientific Team, 1980). Although we have no data bearing on the rate of water movement within the crust at Site 456 , hot water there as well was channeled within the basement in a very narrow zone. But impermeable sediments forced the flow laterally, so that the most intense zone of alteration was precisely at the sediment/ basalt interface.

A model recently proposed by Edmond, Measures, et al. (1979) to explain the range of geothermally produced sedimentary facies at rise crests can be adapted to explain the zones of nonoxidative and oxidative alteration at Site 456 . This model invokes simple mixing of hightemperature nonoxidative fluids venting onto the seafloor. Sulfide deposits, iron hydroxides, and manganese oxides represent successive increments of mixing (i.e., 
Table 1. Microprobe analyses of plagioclases.

\begin{tabular}{|c|c|c|c|c|c|c|c|c|c|c|c|c|c|c|c|c|c|c|}
\hline & \multicolumn{10}{|c|}{ Sample 456-16-1, 45-47 cm } & \multicolumn{8}{|c|}{ Sample 456A-11-1, 76-78 cm } \\
\hline & \multicolumn{2}{|c|}{ M } & \multicolumn{2}{|c|}{ M } & \multicolumn{2}{|c|}{$\mathrm{M}$} & \multicolumn{2}{|l|}{$P$} & \multicolumn{2}{|c|}{$\mathrm{P}$} & \multicolumn{2}{|c|}{ M } & \multicolumn{2}{|c|}{$\mathrm{P}$} & \multicolumn{2}{|c|}{ P } & \multicolumn{2}{|c|}{ MP } \\
\hline $\mathrm{SiO}_{2}$ & 50.92 & & 51.72 & & 51.35 & & 49.69 & & 50.50 & & 51.06 & & 49.82 & & 53.89 & & 51.31 & \\
\hline $\mathrm{Al}_{2} \mathrm{O}_{3}$ & 30.47 & & 30.10 & & 30.18 & & 31.53 & & 31.41 & & 29.74 & & 31.21 & & 24.47 & & 29.47 & \\
\hline $\mathrm{FeO}$ & 0.83 & & 0.83 & & 0.74 & & 0.49 & & 0.53 & & 0.80 & & 0.75 & & 0.59 & & 0.80 & \\
\hline $\mathrm{MgO}$ & 0.25 & & 0.29 & & 0.31 & & 0.15 & & 0.21 & & 0.40 & & 0.23 & & 0.15 & & 0.37 & \\
\hline $\mathrm{CaO}$ & 14.86 & & 14.20 & & 13.68 & & 15.31 & & 13.67 & & 14.08 & & 14.92 & & 11.26 & & 12.45 & \\
\hline $\mathrm{Na}_{2} \mathrm{O}$ & 3.39 & & 3.61 & & 3.61 & & 2.85 & & 3.04 & & 3.45 & & 2.96 & & 5.48 & & 3.70 & \\
\hline $\mathrm{K}_{2} \mathrm{O}$ & 0.09 & & 0.06 & & 0.01 & & 0.00 & & 0.07 & & 0.00 & & 0.06 & & 0.05 & & 0.00 & \\
\hline $\mathrm{TiO}_{2}$ & 0.03 & & 0.02 & & 0.00 & & 0.00 & & 0.04 & & 0.02 & & 0.00 & & 2.75 & & 0.08 & \\
\hline Total & 100.84 & & 100.84 & & 99.87 & & 100.03 & & 99.47 & & 99.55 & & 99.95 & & 98.63 & & 98.19 & \\
\hline $\mathrm{Ab}$ & 29.10 & & 31.41 & & 32.28 & & 25.19 & & 28.57 & & 30.73 & & 26.30 & & 46.69 & & 34.98 & \\
\hline Or & 0.50 & & 0.37 & & 0.04 & & 0.00 & & 0.43 & & 0.00 & & 0.35 & & 0.28 & & 0.00 & \\
\hline \multirow[t]{2}{*}{ An } & 70.40 & & 68.22 & & 67.67 & & 74.81 & & 71.00 & & 69.27 & & 73.35 & & 53.03 & & 65.02 & \\
\hline & \multicolumn{10}{|c|}{ Cations per 32 Oxygens } & \multicolumn{8}{|c|}{ Cations per 32 Oxygens } \\
\hline $\mathrm{Si}$ & 9.25 & & $9.37)$ & & $9.37)$ & & $9.09)$ & & 9.23 & & $9.37 \mid$ & & 9.13 & & 9.95 & & $9.49 \mid$ & \\
\hline Al & 6.53 & 315.91 & 6.43 & 15.93 & 6.49 & 15.97 & 6.80 & 15.96 & 6.77 & 16.09 & 6.43 & 15.92 & 6.74 & 15.98 & 5.33 & 15.75 & 6.43 & 16.05 \\
\hline $\mathrm{Fe}$ & 0.13 & $(15.91$ & 0.13 & 15.93 & 0.11 & 10.91 & 0.07 & & 0.08 & & 0.12 & & 0.11 & & 0.09 & & 0.12 & \\
\hline $\mathrm{Ti}$ & 0.004 & & 0.003 & & 0.00 & & 0.00 & & 0.01 & & $0.003)$ & & 0.00 & & 0.38 & & 0.01 & \\
\hline $\mathrm{Mg}$ & 0.07 & & 0.08 & & 0.08 & & 0.04 & & 0.06 & & 0.11 & & 0.06 & & 0.04 & & 0.10 & \\
\hline $\mathrm{Ca}$ & 2.89 & 4.18 & 2.76 & 4.12 & 2.68 & 4.05 & 3.00 & 4.06 & 2.86 & 3.83 & 2.77 & 4.11 & 2.93 & 4.05 & 2.23 & 4.24 & 2.47 & 3.90 \\
\hline $\begin{array}{l}\mathrm{Na} \\
\mathrm{K}\end{array}$ & 1.19 & & 1.27 & & 1.28 & & 1.01 & & 1.08 & & $\begin{array}{l}1.23 \\
0.90\end{array}$ & & 1.05 & & 1.96 & & 1.33 & \\
\hline K & 0.02 & & 0.01 & & $0.002)$ & & 0.00 & & 0.01 & & 0.00 & & 0.01 & & 0.01 & & $0.00 \mathrm{~J}$ & \\
\hline Total & 20.09 & & 20.05 & & 20.02 & & 20.02 & & 19.92 & & 20.03 & & 20.04 & & 19.99 & & 19.95 & \\
\hline
\end{tabular}

Note: $\mathrm{M}=$ microlite; $\mathrm{MP}=$ microphenocryst $\mathrm{P}=$ phenocryst.

dilution of the hydrothermal component) with seawater. There is commensurate temperature reduction and oxidation. Sulfide deposits do not occur at all rise crests, hence Edmond et al. (1979) propose that much of this mixing (and sulfide precipitation) can occur within the crust.

We propose that a similar phenomenon occurred within the basalts at Site 456 . The little-diluted hydrothermal fluids moved within the uppermost, highly permeable pillows beneath the sediment cap, intensely altering the basalts at high temperatures and precipitating sulfides. Below this was a zone where the high-temperature fluids mixed with colder, oxygenated fluids that probably had essentially seawater compositions and were originally present in interpillow voids. Under these conditions, iron hydroxides and smectites were stable. The latter allowed uptake of $\mathrm{K}$ and $\mathrm{Rb}$. Only a few meters below, the effects of dilution and cooling of the high-temperature fluids were so extensive that little alteration occurred.

At this point we cannot be specific about other conditions of alteration such as $\mathrm{Eh}$ and $\mathrm{pH}$. Both temperature and fugacity of sulfur can dramatically shift the phase relations among pyrite, pyrrhotite, and various iron oxides (Holland, 1959; Garrels and Christ, 1965). The experimental data of Crerar and Barnes (1976) favor mobilization of $\mathrm{Cu}$ under acidic conditions, and the sulfides evidently imply reducing conditions as well. Hydrothermal fluids emanating at ridge crests evidently are both quite acid and reducing (Edmond, Measures, et al., 1979; Haymon and Kastner, in press, citing data of John Edmond). But the conditions around any particular vent should be quite variable, depending on the effects of mixing.

\section{PRESENT-DAY GEOTHERMAL ACTIVITY AT SITE 456}

Heat flow measured in the two holes at Site 456 was different: 2.5 heat flow units in Hole 456 and 1.7 in Hole 456A (Uyeda and Horai, this volume). These suggest temperatures at the top of basement of only a few degrees. Clearly, the high-temperature phase of alteration has passed. However, the quite different and still rather high values of heat flow imply that a conductive geothermal gradient has not yet been established in the region around the site and that seawater is still being convected geothermally within the basement.

\section{CONCLUSIONS}

We have summarized mineralogical evidence for an episode of high-temperature $\left(200^{\circ} \mathrm{C}\right.$ or more) hydrothermal alteration in two basement holes drilled near each other at Site 456 in the Mariana Trough. The basalts have been altered to greenschist facies assemblages and carry various secondary sulfides.

The alteration is significant because it is concentrated in a narrow zone in basement, diminishing sharply downward in the two holes cored at the site. It may therefore be representative of the type of narrowly focused geothermal flux common on rise or ridge crests which can supply hot water to seafloor vents such as those found at $21^{\circ} \mathrm{N}$ on the East Pacific Rise. If so, it is the first such zone ever sampled within basaltic basement. In this case, a high sedimentation rate in the late Pliocene and early Pleistocene $\left(10-15 \mathrm{~kg} / \mathrm{cm}^{2}\right.$ in about $0.1 \mathrm{~m} . \mathrm{y}$.) - that is, just after eruption of the basalts (see Site 456 report, Fig. 8, this volume)-formed a nearly impermeable cap to basement, forcing hydrothermal 
Table 1. (Continued).

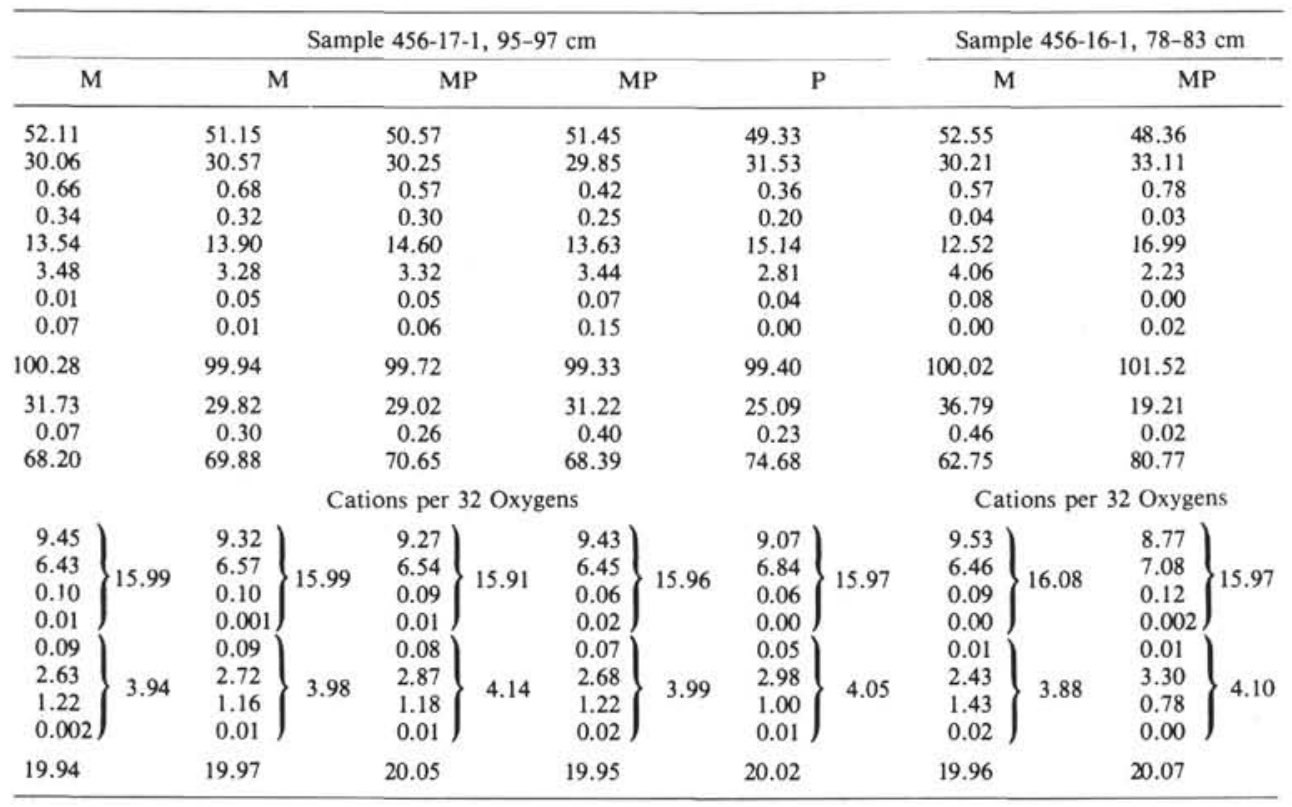

Table 2. Microprobe analyses of chlorites and sphenes.

\begin{tabular}{|c|c|c|c|c|c|c|c|c|}
\hline \multirow[b]{3}{*}{$\mathrm{SiO}_{2}$} & \multicolumn{5}{|c|}{ Sample 456A-11-1, 54-55 cm } & & & \\
\hline & \multicolumn{3}{|c|}{ Chlorites } & \multicolumn{2}{|c|}{ Sphenes } & & & \\
\hline & 33.03 & 32.78 & 32.45 & 30.85 & 32.75 & & & \\
\hline $\mathrm{Al}_{2} \mathrm{O}_{3}$ & 16.05 & 15.91 & 15.54 & 2.99 & 7.64 & & & \\
\hline $\mathrm{FeO}^{*}$ & 19.59 & 19.58 & 18.85 & 1.76 & 7.87 & & & \\
\hline $\mathrm{MgO}$ & 17.22 & 17.96 & 17.33 & 0.28 & 4.56 & & & \\
\hline $\mathrm{CaO}$ & 0.15 & 0.20 & 0.57 & 26.24 & 19.58 & & & \\
\hline $\mathrm{Na}_{2} \mathrm{O}$ & 0.38 & 0.37 & 0.29 & 0.04 & 0.36 & & & \\
\hline $\mathrm{K}_{2} \mathrm{O}$ & 0.09 & 0.08 & 0.03 & 0.00 & 0.13 & & & \\
\hline $\mathrm{TiO}_{2}$ & 0.02 & 0.00 & 0.03 & 31.42 & 21.02 & & & \\
\hline $\mathrm{Cr}_{2} \mathrm{O}_{3}$ & 0.00 & 0.13 & 0.41 & 0.05 & 0.06 & & & \\
\hline $\mathrm{NiO}$ & 0.00 & 0.00 & 0.00 & 0.00 & 0.00 & & & \\
\hline $\mathrm{MnO}$ & 0.59 & 0.49 & 0.36 & 0.08 & 0.15 & & & \\
\hline \multirow[t]{2}{*}{ Total } & 87.12 & 87.51 & 85.86 & 93.70 & 94.12 & & & \\
\hline & \multicolumn{3}{|c|}{ Cations per $28 \mathrm{O}, \mathrm{OH}$} & \multicolumn{5}{|c|}{ Cations per $20 \mathrm{O}, \mathrm{OH}$} \\
\hline $\mathrm{Si}$ & 6.72 & 6.65 & 6.69 & $\mathrm{Si}$ & 4.27 & & 4.50 & \\
\hline Al & 3.85 & 3.81 & 3.79 & $\mathrm{Ti}$ & 3.27 & & 2.17 & \\
\hline $\mathrm{Fe}$ & 3.34 & 3.32 & 3.25 & Al & 0.48 & 3.95 & 1.24 & 4.31 \\
\hline $\mathrm{Mg}$ & 5.77 & 5.43 & 5.33 & $\mathrm{Fe}$ & 0.20 & & 0.90 & \\
\hline $\mathrm{Ca}$ & 0.03 & 0.04 & 0.13 & $\mathrm{Mg}$ & 0.06 & & 0.93 & \\
\hline $\mathrm{Na}$ & 0.15 & 0.15 & 0.12 & $\mathrm{Ca}$ & 3.89 & & 2.88 & \\
\hline K & 0.02 & 0.02 & 0.07 & $\mathrm{~K}$ & 0.00 & 3.97 & 0.02 & 3.95 \\
\hline $\mathrm{Ti}$ & 0.002 & & 0.01 & $\mathrm{Na}$ & 0.01 & & 0.10 & \\
\hline $\mathrm{Cr}$ & & 0.02 & 0.07 & $\mathrm{Mn}$ & 0.01 & & 0.02 & \\
\hline $\begin{array}{l}\mathrm{Ni} \\
\mathrm{Mn}\end{array}$ & 0.10 & 0.08 & 0.06 & Total & 12.19 & & 12.76 & \\
\hline Total & 19.99 & 19.52 & 19.51 & & & & & \\
\hline
\end{tabular}

fluids to migrate laterally, altering the basalts as they went. There may be actual vents through the sediments along faults or near basement highs adjacent to the site that could be investigated for geothermal phenomena. The actively spreading Mariana Trough axis is only about $22 \mathrm{~km}$ to the west and may also be experiencing locally high sediment accumulation rates. High-temperature geothermal vents thus might be accessible to the drill string in the Mariana Trough.
Table 3. Microprobe analyses of sulfides.

\begin{tabular}{|c|c|c|c|c|c|c|}
\hline \multicolumn{7}{|c|}{ Sample $456-16-1,146-148 \mathrm{~cm}^{\mathrm{a}}$} \\
\hline $\mathrm{S}$ & 51.71 & 51.99 & 50.65 & 52.77 & & \\
\hline $\mathrm{Fe}$ & 44.89 & 44.85 & 43.47 & 45.71 & & \\
\hline $\mathrm{Cu}$ & 0.09 & 0.11 & 0.08 & 0.17 & & \\
\hline $\mathrm{Ni}$ & 0.03 & 0.05 & 0.02 & 0.06 & & \\
\hline $\mathrm{Pb}$ & n.d. & n.d. & n.d. & n.d. & & \\
\hline $\mathrm{Zn}$ & n.d. & n.d. & n.d. & n.d. & & \\
\hline & 96.72 & 97.00 & 94.22 & 98.71 & & \\
\hline \multicolumn{7}{|c|}{ Sample 456-17-1, 95-97 $\mathrm{cm}^{\mathrm{b}}$} \\
\hline & Pyrite & Pyrite & \multicolumn{4}{|c|}{ Cu-bearing } \\
\hline \multirow{6}{*}{$\begin{array}{l}\mathrm{S} \\
\mathrm{Fe} \\
\mathrm{Cu} \\
\mathrm{Ni} \\
\mathrm{Pb} \\
\mathrm{Zn}\end{array}$} & 54.17 & 54.56 & 52.09 & 35.16 & 34.84 & 35.13 \\
\hline & 45.88 & 45.89 & 41.42 & 29.61 & 28.93 & 30.13 \\
\hline & & & 7.37 & 33.30 & 32.41 & 33.50 \\
\hline & & 0.03 & & & & \\
\hline & 10005 & 10048 & 10140 & 0807 & 9618 & 9939 \\
\hline & Digenite & & & & & \\
\hline \multirow{7}{*}{$\begin{array}{l}\mathrm{S} \\
\mathrm{Fe} \\
\mathrm{Cu} \\
\mathrm{Ni} \\
\mathrm{Pb} \\
\mathrm{Zn}\end{array}$} & 29.84 & & & & & \\
\hline & 1.75 & & & & & \\
\hline & 65.47 & & & & & \\
\hline & & & & & & \\
\hline & & & & & & \\
\hline & & & & & & \\
\hline & 97.06 & & & & & \\
\hline
\end{tabular}

a Smithsonian.

${ }^{\mathrm{b}}$ CNEXO.

Site 456 (and also Site 453) are definite proof that high-temperature near-surface zones of hydrothermal discharge can occur on slow-spreading ridges, although admittedly the Mariana Trough differs in important 
Table 4. Chemical analyses of altered basalts.

\begin{tabular}{lcccc}
\hline & 1 & 2 & 3 & 4 \\
\hline $\mathrm{SiO}_{2}$ & 49.3 & 46.2 & 48.2 & 52.5 \\
$\mathrm{TiO}_{2}$ & 1.25 & 1.25 & 1.38 & 1.30 \\
$\mathrm{Al}_{2} \mathrm{O}_{3}$ & 14.5 & 12.3 & 14.0 & 16.2 \\
$\mathrm{TFe}_{2} \mathrm{O}_{3}$ & 10.07 & 10.22 & 11.17 & 10.48 \\
$\mathrm{MnO}$ & 0.17 & 0.29 & 0.21 & 0.17 \\
$\mathrm{MgO}$ & 10.37 & 11.22 & 15.28 & 4.33 \\
$\mathrm{CaO}$ & 8.66 & 12.55 & 4.18 & 9.52 \\
$\mathrm{Na}_{2} \mathrm{O}$ & 3.34 & 2.40 & 2.44 & 3.43 \\
$\mathrm{~K}_{2} \mathrm{O}$ & 0.09 & 0.06 & 0.06 & 0.98 \\
$\mathrm{P}_{2} \mathrm{O} 5$ & 0.09 & 0.11 & 0.09 & 0.15 \\
$\Sigma$ & 97.92 & 96.56 & 96.99 & 99.10 \\
$\mathrm{Rb}$ & $<1$ & $<1$ & $<1$ & 12 \\
$\mathrm{Ba}$ & 109 & 67 & 54 & 87 \\
$\mathrm{Zn}$ & 118 & 93 & 198 & 79 \\
$\mathrm{~Pb}$ & - & - & 5 & $<1$ \\
\hline
\end{tabular}

Note: Data from Wood et al. (this volume). Chloritized, pyritized basalts: Analysis 1 . Sample 456-16-1, 145-147 cm. Analysis 2 . Sample 456-16-2, 92-94 cm. Analysis 3 . Sample 456A-11-1, 76-78 cm. Oxidatively altered, clay-rich basalt: Analysis 4. Sample 456A-14-1, 12-14 cm.

ways tectonically from the Mid-Atlantic Ridge. Presently there are too few known high-temperature vents, or sulfide occurrences, to generalize about their distribution on ridges with different spreading rates.

The zonation in the basalts at Site 456 , although small in scale, is reminiscent of zoning in larger ore bodies of submarine origin in island arcs and ophiolites and may therefore have a similar origin. The Kuroku deposits of western Japan are described by Sato (1974) as being "stratiform or lenticular ore bodies that are concordant with the surrounding sediments (p. 1)." Similarly, the Kokkinoyia ore body of the Troodos ophiolites, which formed within pillow lavas, has a narrow sulfide-bearing stockwork leading upward to a broadly lenticular mass (Constantinou and Govett, 1973). Both the Kuroku and Troodos deposits are zoned, with the most massive and $\mathrm{Cu}-, \mathrm{Zn}-$, or $\mathrm{Pb}$ bearing sulfides, concentrated toward the tops of the ore bodies. One important difference seems to be that oxidized zones in both the Kuroku-type and Troodos deposits are at the top not the base of the ore bodies. Nevertheless, there is a clear tendency for these ore bodies to diverge laterally from a narrow stockwork source, clearly following zones of high permeability in sediments or submarine lavas.

\section{ACKNOWLEDGMENTS}

We thank Stan Kling for assisting with the SEM and J. Nelen for help in obtaining the sulfide microprobe analyses at the Smithsonian
Institution. Rachel Haymon and Andy Adamson reviewed the manuscript.

\section{REFERENCES}

Cann, J. R., 1969. Spilites from the Carlsberg Ridge, Indian Ocean. J. Petrol., 10:1-19.

Constantinou, G., and Govett, G. J. S., 1973. Geology, geochemistry, and genesis of Cyprus sulfide deposits. Econ. Geol., 68:843858.

Crerar, D. A., and Barnes, H. L., 1976. Ore solution chemistry V. Solubilities of chalcopyrite and chalcocite assemblages in hydrothermal solution at $200^{\circ}$ to $350^{\circ} \mathrm{C}$. Econ. Geol., 71:772-794.

Edmond, J. M., Craig, H., Gordon, L. I., et al., 1979. Chemistry of hydrothermal waters at $21^{\circ} \mathrm{N}$ on the East Pacific Rise. Eos, Trans. Am. Geophys. Union, 60:864.

Edmond, J. M., Measures, C., Mangum, B., et al., 1979. On the formation of metal-rich deposits at ridge crests. Earth Planet. Sci. Lett., 46:19-30.

Elders, W. A., Hoagland, J. R., McDowell, S. D., et al., 1979. Hydrothermal mineral zones in the geothermal reservoir of Cerro Prieto. In Elders, W. A. (Ed.), Geology and Geothermics of the Salton Trough, GSA Guidebook, U.C. Riverside Campus Museum Contrib. 5, 36-43.

Garrels, R. A., and Christ, C. L., 1964, Solutions, Minerals, and Equilibria: New York (Harper and Row).

Haymon, R. M., and Kastner, M., in press. Hot spring deposits on the East Pacific Rise at $21^{\circ} \mathrm{N}$ : Preliminary description of mineralogy and genesis. Earth Planet. Sci. Lett.

Hekinian, R., Fevrier, M., Bischoff, J. L., et al. 1980. Sulfide deposits from the East Pacific Rise near $21^{\circ} \mathrm{N}$. Science, 207:1433-1444.

Holland, H. D., 1959. Some applications of thermochemical data to the problems of ore deposits 1. Stability relations among the oxides, sulfides, sulfates, and carbonates of ore and gangue metals. Econ. Geol., 54:184-225.

Humphris, S. E., and Thompson, G., 1978. Hydrothermal alteration of oceanic basalts by seawater. Geochim. Cosmochim. Acta, 42:107-125.

Kristmannsdottir, H., 1976. Types of clay minerals in hydrothermally altered basaltic rocks, Reykjanes, Iceland. Jökull, 26:30-39.

Liou, J. G., 1971. P-T stabilities of laumontite, wairakite, lawsonite, and related minerals in the system $\mathrm{CaAl}_{2} \mathrm{Si}_{2} \mathrm{O}_{8}-\mathrm{H}_{2} \mathrm{O}$. J. Petrol., 12:379-411.

Melson, W. G., and van Andel, Tj. H., 1966. Metamorphism in the Mid-Atlantic Ridge, $22^{\circ} \mathrm{N}$ Latititude. Mar. Geol., 4:165-186.

Mottl, M. J., and Holland, H. D., 1978. Chemical exchange during hydrothermal alteration of basalt by seawater-I. Experimental results for major and minor components of seawater. Geochim. Cosmochim. Acta, 42:1103-1115.

RISE Scientific Team, 1980. East Pacific Rise: Hot springs and geophysical experiments. Science, 207:1421-1432.

Sato, T., 1974. Distribution and geological setting of Kuroku deposits. Mining Geology Special Issue 6 (Japan Geological Survey): $1-9$.

Seki, Y., 1973. Distribution and modes of occurrence of wairakites in the Japanese island arc. J. Geol. Soc. Jpn., 79:521-527.

Seyfried, W. E., and Bischoff, J. L., 1977. Hydrothermal transport of heavy metals by seawater: The role of seawater/basalt ratio. Earth Planet. Sci. Lett., 34:71-77.

Tomasson, J., and Kristmannsdottir, H., 1972. High temperature alteration minerals and thermal brines, Reykjanes, Iceland. Contrib. Mineral. Petrol., 36:123-134. 

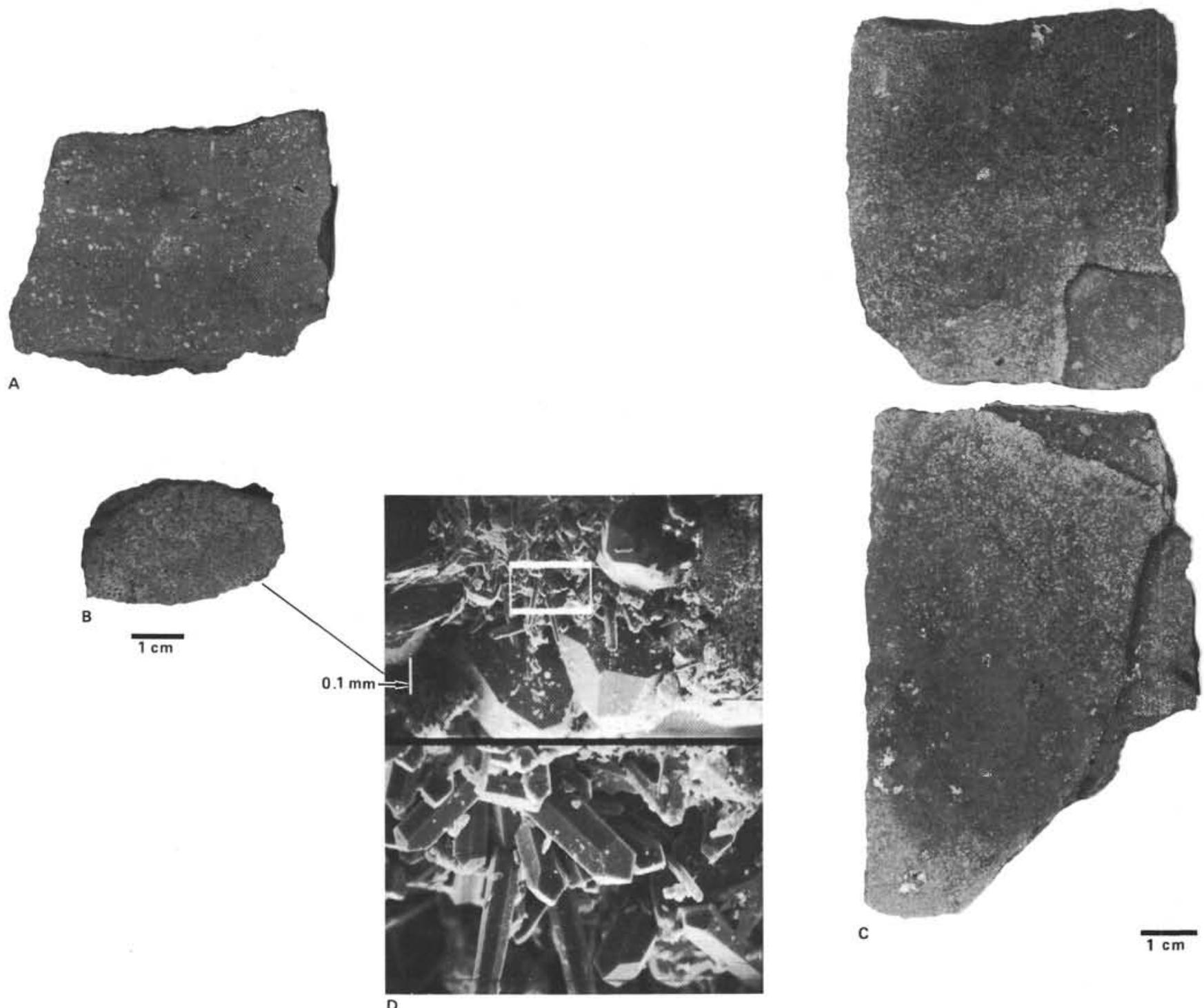

Figure 6. Examples of recrystallized sediments just above, and incorporated within, basalt at Site 456. A and B are recrystallized vitric tuff fragments just above basalt, Section 456-16-1, Pieces 2 and 3, respectively. C shows a recrystallized tuffaceous xenolith within basalt, Section 456-16-1, Pieces 7a (top) and 7b. D is a scanning electron micrograph of a portion of Section 456-16-1, Piece 3, shown in B. The upper micrograph shows large crystals of wairakite, smaller crystals of quartz, and a thin coating of illite. The inset is enlarged in the lower micrograph to show the quartz crystals in more detail. 